\title{
Term pregnancy with gastroschisis presenting as prolapsed bowel loops
}

\author{
Najam R, Jain M, Lalwani A \\ Department of Obstetrics and Gynecology, Teerthanker Mahaveer Medical College and Research Centre, India.
}

\section{Dear Editor,}

Gastrochisis and omphalocele are the two most common congenital anterior abdominal wall defects. ${ }^{1}$ These conditions can be diagnosed in the antenatal period with routine ultrasound scanning and maternal serum screening. However in the developing countries due to ignorance and lack of regular antenatal visits routine scanning of all the patients is not done.

A number of such cases are diagnosed either after delivery or present with complications of labour. We present an interesting case of term pregnancy with prolapsed fetal bowel loops into the introitus. The fetus was in transverse lie.

A 30 year old female patient presented with eight and half months of pregnancy with labour pains in the casualty department of Teerthanker Mahaveer Medical college and Research Centre. She was a primipara, with no history of antenatal visits and her last menstrual period was not known to her. She had undergone trial of labor at some other limited resource centre and was referred to our hospitalfrom there. On physical examination, her vitals were stable, the uterus was 32 weeks size with good uterine contractions and fetus was in transverse lie. Fetal heart sound could not be localised. Local examination revealed fetal bowel loops coming out from the introitus. On per vaginal examination the cervix was fully dilated and effaced and shoulder of fetus was felt. Her routine investigations

\section{CORRESPONDENCE}

Dr Rehana Najam

Department of Obstetrics and Gynecology

Teerthanker Mahaveer Medical College and Research

Centre,Teerthanker Mahaveer university,

Delhi road, Moradabad, India.

Email: najamnajam@rediffmail.com were normal. Ultrasound scan of antenatal period was unavailable. Clinical diagnosis of term pregnancy with gastrochisis with intrauterine death with transverse lie was made. Patient was shifted to the operating room. Under general anesthesia internal podalic version was done and delivery was conducted as breech. A dead female baby of $2.5 \mathrm{~kg}$ weight with a big left sided gastrochisis with liver protrusion was delivered. No other obvious congenital malformation was found. The post operative period was uneventful. Postmortem of baby was not done because of religious concerns of the patient's family.

Incidence of gastrochisis is $0.4-3 / 10,000$ birth and omphalocele ranges between $1.5-3 / 10,000 .^{2}$ The majority of pregnancies complicated by gastrochisis can be diagnosed prenatally by routine ultrasound scanning. ${ }^{3}$ Elevated maternal serum alfa feto protein level may be the earliest indicator of the presence of gastrochisis.

These pregnancies are high risk with an increased risk of preterm delivery, intra uterine growth retardation and fetal death. ${ }^{4-6} t$ is necessary to deliver such patients at a tertiary care centre with good neonatology and paediatric surgery units for proper management and repair.

This case is unique as the patient presented at term with transverse lie with prolapsed fetal bowel loops. Most of the cases reported previously are with early pregnancy. There is only one similar case reported in literature by Parulekar et al. ${ }^{7}$ Hence, to conclude that prenatal diagnosis
The papers in this journal are published under the terms of the Creative Commons Attribution License. Users are allowed to read, download, copy, distribute, print, search, or link to the full texts of the articles in this journal without asking prior permission from the publisher or the author. 
of gastrochisis influences the timing, mode and location of delivery. An important aspect is training and education of midwives and routine ultra sonography of all antenatal patients for early detection to reduce the perinatal mortality and morbidity.

\section{REFRENCES}

1. Christison L, Agay ER, Kelleher CM, Langer JC. Neonatal abdominal wall defects. Semin Fetal and Neonatal Med. 2011;16(3):164-72.

2. Ledbetter DJ. Gastrochisis and omphalocele. Surg Clin North Am 2006;86:24-6.

3. Rasmussen SA, Frias JL. Nongenetic risk factors for gastrochisis. Am J Med Genet. 2008;148:199-212.
4. Lausman AY, Langer JC, Tai M. Gastrochisis: what is the average gestational age of spontaneous delivery. I Paediatric Surg. 2007;42:1816-21.

5. Kronfi R, Bradnock TJ, Sabharwal A. Intestinal atresia in association with gastrochisis: a 26 years review. J Paediatric Surg. 2010;26:89-4.

6. Arnold MA, Chang DC, Nabawersi R, Colombani PM, Bathurst MA Mon KS, et al. Risk stratification of 4344 patients with gastrochisis into simple and complex categories. J Paediatr Surg. 2007;42(9):1520-5

7. Parulekar SV, Shobha, Joglekar JJ, Madhav HT. Gastrochisis in pregnancy. J Postgrad Med. 1984;30:189. 